\title{
Індивідуалізований підхід до факторної терапії гемофілії: можливості сучасних технологій
}

\author{
О.В. Стасишин \\ ДУ «Інститут патології крові та трансфузійної медицини НАМН України», Львів, Україна
}

Гемофілія - спадкове захворювання системи гемостазу, що характеризується дефіцитом або відсутністю факторів згортання крові: VIII (FVIII) при гемофілії типу A, IX (FIX) - B. Хвороба має X-зчеплений тип успадкування, відповідно, більшість хворих на гемофілію - чоловічої статі. Сьогодні гемофілія — одна з найпоширеніших та найтяжчих форм спадкових коагулопатій, яка становить не лише непросту медичну проблему, а й впливає на соціальний аспект, що пов'язано з ранньою інвалідизацією пацієнтів ще у дитячому віці. За оцінками Всесвітньої федерації гемофілії (World Federation of Hemophilia - WFH), >400 тис. осіб в усьому світі живуть із гемофілією і лише $25 \%$ отримують адекватне лікування [1]. Поширеність гемофілії А становить 1:10 тис., гемофілія В менш поширена - 1:30-50 тисяч [2]. Гемофілія A - найпоширеніший тип гемофілії, який становить >80\% популяції пацієнтів із гемофілією.

Тяжкість клінічного перебігу гемофілії залежить від ступеня недостатності коагуляційної активності FVIII. Залежно від клінічних проявів захворювання виділяють три форми гемофілії: легку, середньої тяжкості й тяжку (табл. 1). Нормальним вважають рівень активності фактора згортання крові 50-150\% [3]. Залежно від активності фактора згортання у пацієнтів превалює специфічна клінічна картина. Діагноз «тяжка форма гемофілії» зазвичай встановлюють у ранньому віці на підставі непояснених кровотеч і гематом, що виникають у неонатальний період і після того, як дитина починає повзати.

Сьогодні золотим стандартом лікування пацієнтів із гемофілі$\epsilon ю \mathrm{~A} \in$ призначення профілактичного лікування концентратами FVIII з метою зниження ризику кровотеч і запобігання розвитку тяжкої артропатії внаслідок частих гемартрозів. Первинна профілактика - стандарт лікування пацієнтів із гемофілією $A$, що характеризується регулярним введенням концентратів FVIII у дозі 25-40 Од./кг маси тіла з метою профілактики кровотеч [4]. Вторинна профілактика призначається пацієнтам з наявними ознаками ураження суглобів і спрямована на зменшення прогресування гемофілічної артропатії. Профілактичне введення фактора крові дозволяє пацієнтам із гемофілією вести активне життя та досягти його нормальної якості, зіставної з таким у осіб без гемофілії.

У рандомізованому дослідженні A. Gringeri та співавторів (2011) [5] підтверджено ефективність профілактичного лікування щодо зменшення вираженості й запобігання кровотечам і артропатіям у дітей із гемофілією. Концепція профілактичного лікування базується на клінічному спостереженні, що у пацієнтів із середньотяжкою формою гемофілії А спостерігали нижчу частоту кровотеч, включно з гемартрозами, та рідше розвивалися артропатії порівняно з особами з тяжкою формою гемофілії [6]. Відповідно, з метою забезпечення зниження частоти кровотеч та зменшення розвитку артропатії необхідною $\epsilon$ підтримка активності FVIII у межах >1\%. Проте дані літератури свідчать, що в окремих пацієнтів не завжди вдається знизити річну частоту кровотеч і гемартрозів як мінімум до двох епізодів на рік на фоні стандартної профілактичної терапії, що пов'язано з індивідуальною фармакокінетичною відповіддю на введення FVIII $[7,8]$.

Фармакокінетика - розділ фармакології, що вивчає шляхи надходження препарату в організм, його абсорбцію, розподіл, метаболізм, кліренс. Визначення фармакокінетики фактора згортання полягає у проведенні оцінки фактора за такими показниками: період напіввиведення, площа під кривою, кліренс і відновлення ак- тивності фактора згортання. Фармакокінетика дозволяє визначити, які зміни активності фактора, пов'язані з часом, відбуваються після його внутрішньовенного введення. При внутрішньовенному введенні FVIII 1 Од./кг приводить до підвищення активності FVIII у сироватці крові на 2\%, відповідно, введення 40 Од./кг FVIII приведе до підвищення активності FVIII у сироватці крові до 80\% - пікова активність фактора (нормальна активність FVIII 50-150\%) (рис. 1). Після досягнення фактором пікової активності його концентрація у сироватці крові буде поступово знижуватися.

Стандартна профілактика, тобто введення препарату FVIII в дозі 20-40 Од./кг 3-4 рази на тиждень, є загальноприйнятим варіантом профілактичного лікування, однак не завжди забезпечує належний клінічний ефект. Це пов'язано з тим, що особи з гемофілією мають цілу низку факторів, включно з віком пацієнта, способом життя, масою тіла, фенотипом кровотечі, рівнем фізичної активності, ураженням суглобів, прихильністю пацієнта до терапії та індивідуальну фармакокінетичну відповідь на введення FVIII (рис. 2). Так, наявні дані свідчать, що у дітей із гемофілією А препарат FVIII виводиться з організму швидше, ніж у дорослих, відповідно маленьким дітям потрібна більша кількість FVIII на кілограм маси тіла для підтримки цільового рівня залишкової активності FVIII, ніж дорослим. Крім того, на фармакокінетику фактора впливає спосіб життя пацієнта. Так, залежно від рівня фізичної активності цільова залишкова активність FVIII може становити 2; 3 або навіть 5\%. Враховуючи те що фізична активність $\epsilon$ ваговим фактором впливу на фармакокінетичний профіль, у 2017 р. розроблені рекомендації щодо мінімальної концентрації FVIII у сироватці крові, залежно від віку та активності пацієнта (табл. 2) [9].

Кожний пацієнт $\epsilon$ унікальним, відповідно, оптимізація профілактичної терапії необхідна всім хворим, оскільки однакове дозування препаратів факторів відповідно до маси тіла зазвичай неефективне для більшості пацієнтів [11]. У різних пацієнтів відзначають високу варіабельність значень періоду напіввиведення FVIII. Оскільки рівень залишкової активності FVIII напряму пов'язаний із ризиком виникнення спонтанних кровотеч, необхідний контроль рівня фармакокінетичного профілю пацієнта. У цьому разі доцільне застосування індивідуалізованого підходу до профілактичної терапії, який базується на фармакокінетичному профілі [12] (рис. 3).

Таблиця 1 Ступені тяжкості гемофілії залежно від активності фактора згортання крові

\begin{tabular}{|c|c|c|}
\hline \multicolumn{3}{|c|}{ Класифікація гемофілії за ступенем тяжкості } \\
\hline Ступінь тяжкості & $\begin{array}{l}\text { Активність } \\
\text { фактора, \% }\end{array}$ & Клінічна картина \\
\hline Тяжкий & $<1$ & $\begin{array}{l}\text { Прояви захворювання відзначають із раннього } \\
\text { віку (з перших днів/місяців життя), характер- } \\
\text { на наявність тяжкого геморагічного синдрому }\end{array}$ \\
\hline Середньотяжкий & $1-5$ & $\begin{array}{l}\text { Прояви захворювання відзначають } \\
\text { із дошкільного віку, характерна наявність } \\
\text { періодичних спонтанних кровотеч при травмі } \\
\text { або хірургічних втручаннях }\end{array}$ \\
\hline Легкий & $5-50$ & $\begin{array}{l}\text { Характерний розвиток симптоматики } \\
\text { у шкільному віці та кровотечі, які виникають } \\
\text { при серйозній травмі або хірургічних втручаннях }\end{array}$ \\
\hline
\end{tabular}


Рисунок 1 Пікова та мінімальна концентрація FVIII у сироватці крові

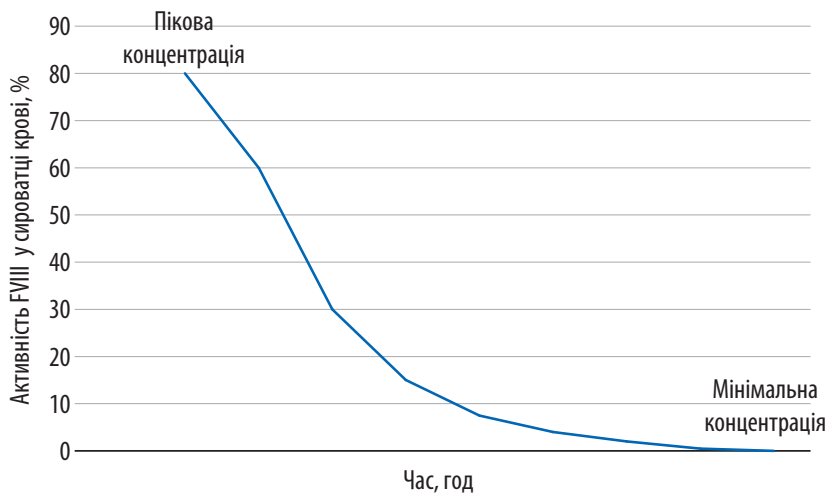

Рисунок 2 Індивідуальні характеристики пацієнта

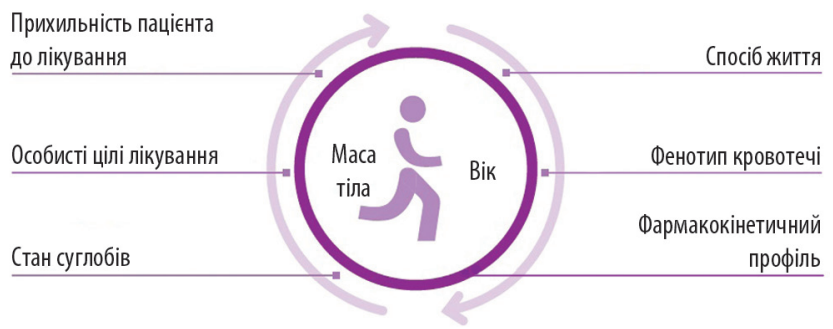

Таблиця 2 Рекомендації щодо мінімальної концентрації FVIII для дітей різних вікових груп

\begin{tabular}{ll}
\hline \multicolumn{2}{c}{ Рекомендації щодо мінімальної концентрації FVIII } \\
\hline $\begin{array}{l}\text { Рекомендована мінімальна } \\
\text { концентрація, \% }\end{array}$ & \multicolumn{1}{c}{ Вікова група } \\
\hline$<1$ & Усі діти до моменту появи перших кровотеч \\
\hline $1-3$ & Усі діти віком <2 років або діти, які ведуть малорухливий \\
& («сидячий») спосіб життя \\
\hline $3-5$ & Діти, яким показана первинна профілактика \\
\hline $5-15$ & Діти, які ведуть активний спосіб життя (фізичні заняття \\
& для групи високого ризику ${ }^{*}$ ) \\
\hline
\end{tabular}

*0цінка видів спорту за шкалою Національного фонду гемофілії (National Hemophilia Foundation - NHF) [10]

Рисунок 3 Розширення можливостей профілактичної терапії упаці$\epsilon$ нтів із гемофілією A

$\begin{array}{lcc}\text { Стандартні } & \text { Фенотипове } & \text { Індивідуалізована профілактика } \\ \text { протоколи } & \text { дозування } & \text { на основі фармакокінетики }\end{array}$

Однакове дозування Інтенсивність дозування При оптимізації лікування враховують: для всіх пацієнтів підвищується індивідуальний профіль на основі маси тіла у увідповідь на кровотечу фармакокінетики, масу тіла, фенотип

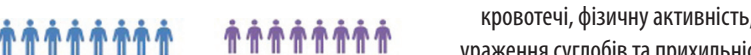

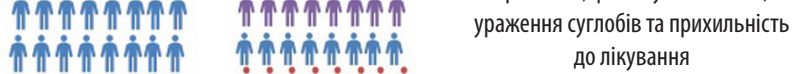

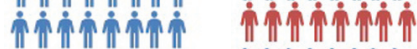

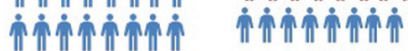
до лікування

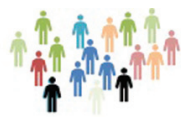

Для пацієнтів, які отримують препарат октоког альфа, розроблено програмне забезпечення myPKFiT на основі webдодатка, що дозволяє моделювати режим дозування з урахуванням фармакокінетичного профілю індивідуально для кожного пацієнта на підставі визначення активності FVIII [13]. Для залучення пацієнтів до підбору терапії та використання myPKFiT необхідно виконати 4 кроки:

1. Оцінка фармакокінетики шляхом введення інформації про інфузії за двома зразкам крові:

- 1-й зразок, узятий через 72 год після останньої інфузії (природний базальний рівень FVIII);

- 2-й зразок, узятий через 3-4 год ( +30 хв) після інфузії;
• 3-й зразок, узятий через 24-32 год ( 11 год) після інфузії.

2. Визначення індивідуального фармакокінетичного профілю пацієнта: оцінка фармакокінетичного профілю, включаючи період напіввиведення FVIII і розрахунковий рівень FVIII у заданий момент часу після інфузії.

3. Визначення схеми дозування: розрахунок схеми на підставі заздалегідь заданого чи індивідуалізованого цільового рівня залишкової активності FVIII та інтервалу дозування.

4. Експорт даних до мобільного додатка: введення даних пацієнта до мобільного додатка mуPKFіТ, що дозволяє пацієнту відстежувати розрахункові рівні фактора, контролювати схему інфузій і залишатися на зв'язку з лікарем.

Персоналізована профілактика за допомогою додатка myPKFiT може використовуватися і у пацієнтів, які отримують руріоктоког альфа пегільований. Додавання поліетиленгліколю (ПЕГ) до рекомбінантного октакогу альфа (ПЕГілювання) забезпечує триваліший період напіввиведення. ПЕГ ніби хмаринкою оточує рекомбінантний FVII та зменшує його зв'язування з фізіологічним рецептором кліренсу FVIII (LRP1) в печінці. Порівняно з октокогом альфа період напіввиведення подовжений у 1,4 раза, це зумовлює можливість збільшення інтервалів введення, що потребує меншої кількості інфузій. У разі введення з однаковою частотою зі звичайними рекомбінантними препаратами FVIII, пегільовані препарати подовженої дії допоможуть досягти вищих мінімальних рівнів фактора та знизити ризик кровотеч [16]. Пегілювання також знижує імуногенність рекомбінантного FVIII, при призначенні руріоктокогу альфа пегільованого двічі на тиждень упродовж 6 міс із профілактичною метою не виявлено розвитку інгібіторів до FVIII [17].

Таким чином, індивідуалізований підхід до профілактичної терапії дає можливість адаптувати режим дозування препарату фактора крові залежно від індивідуальних характеристик пацієнта, виходячи з цільового рівня залишкової активності фактора згортання, з метою зниження ризику кровотеч. Крім того, оптимізація профілактичної терапії дає можливість грамотно планувати фізичну активність пацієнта, тим самим покращуючи якість його життя. Такий підхід забезпечує, щоб піки активності фактора припадали на фізичну активність пацієнта, а мінімальна активність фактора - на період сну або спокою [9]. Цей підхід сприятиме підвищенню прихильності пацієнта до терапії та дозволить контролювати перебіг захворювання [14, 15].

За підтримки ТОВ «Такеда-Україна» VV-MEDMAT-37034

\section{Список використаної літератури/References:}

1. Srivastava A., Santagostino E., Dougall A. et al. (2020) WFH Guidelines for the Management of Hemophilia, $3^{\text {rd }}$ ed. Haemophilia.

2. Vilchevskaya E. (2018) Hemophilia in Ukraine. Situational analysis based on unmet patient needs. Hematology. Transfusiology. Eastern Europe, 4(4): 456-465 (In Rus.).

3. Windyga J., Chojnowski K., Klukowska A. et al. (2016) Częśćll:Wytyczne postępowania w hemofiliiAiBpowikłanejinhibitorem czynnikaVIIIIIX (2 wydanie). Partll:Guidelines on the management of Haemophilia A and B complicated by factor VIII or IX inhibitors (2nd edition). Acta Haematol. Polonica, 48(3): 137-159 (https://doi.org/10.1016/j.achaem.2017.08.001).

4. Collins P.W., Blanchette V.S., Fischer K. et al. (2009) Breakthrough bleeding in relation to predicted factor VIII levels in patients receiving prophylactic treatment for severe hemophilia A. J. Thromb. Haemost., 7(3): 413-420. doi: 10.1111/j.1538-7836. 2008.03270.x.

5. Gringeri A., Lundin B., von Mackensen S. et al. (2011) A randomized clinical trial of prophylaxis in children with hemophilia A (the ESPRIT Study). J. Thromb. Haemost., 9(4): 700-710. doi: 10.1111/j.1538-7836.2011.04214.x.

6. Hay C.R.M. (2007) Prophylaxis in adults with haemophilia. Haemophilia, 13 (Suppl. 2): 10-15. doi: 10.1111/j.1365-2516.2007.01500.x.

7. Reininger A.J., Chehadeh H.E. (2013) The principles of PK-tailored prophylaxis. Hamostaseologie, 33 Suppl.: S32-S35. D0l: 10.1055/s-0037-1619800.

8. YuJ.K., lorio A., Edginton A.N., WAPPS co-investigators (2019) Using pharmacokinetics for tailoring prophylaxis in people with hemophilia switching between clotting factor products: ascoping review. Res. Pract. Thromb. Haemost., 3(3):528-541. doi: 10.1002/rth2.12204. 
9. Iorio A., Iserman E., BlanchetteV. et al. (2017) Target plasma factor levels for personalized treatment in haemophilia: a Delphi consensus statement. Haemophilia, 23(3): e170-e179. doi: 10.1111/ hae. 13215.

10. NHF (2005) Playing It Safe (https://www.hemophilia.ca/files/PlayingltSafe.pdf).

11. Valentino L.A. (2014) Considerations in individualizing prophylaxis in patients with haemophilia A. Haemophilia, 20(5):607-615. doi: 10.1111/hae.12438.

12. Berntorp E., Shapiro A.D. (2012) Modern haemophilia care. Lancet, 379(9824): 1447-1456. D0I: https://doi.org/10.1016/S0140-6736(11)61139-2.

13. Nishimura S., Tomioka K., Shimomura M. et al. (2017) Pharmacokinetics Using myPKFiTR for Personalized Prophylaxis in Children with Severe Hemophilia A. Blood, 130(Suppl. 1): 2361. https:// doi.org/10.1182/blood.V130.Suppl_1.2361.2361.
14. Álvarez-Román M.T., Fernandez-Bello l., de la Corte-Rodríguez H. etal. (2017) Experience of tailoring prophylaxis using factorVIII pharmacokinetic parameters estimated with myPKFiT ${ }^{\circledR}$ in patients with severe haemophilia A without inhibitors. Haemophilia, 23(1): e50-e54. doi: 10.1111/ hae.13141.

15. Carcao M., Srivastava A. (2016) Factor VIII/factor IX prophylaxis for severe hemophilia. Semin. Hematol., 53(1): 3-9. doi: 10.1053/j.seminhematol.2015.10.006.

16. Berntorp E., Andersson N.G. (2016) Prophylaxis for Hemophilia in the Era of Extended Half-Life FactorVIII/FactorIXProducts.SeminThromb. Hemost., 42(5):518-525.doi:10.1055/s-0036-1571315.

17. Konkle B.A., Stasyshyn 0., Chowdary P. etal. (2015) Pegylated, full-length, recombinant factor VIII for prophylactic and on-demand treatment of severe hemophilia A. Blood, 126(9): 1078-1085. doi: 10.1182/blood-2015-03-630897.

\section{Відомості про автора:}

Стасишин Олександра Василівна — доктор медичних наук, провідний науковий співробітник ДУ «Інститут патології крові та трансфузійної медицини НАМНУкраїни», Львів, Україна. ORCID ID: orcid.org/0000-0002-8366-5926

Адреса для кореспонденції:

Стасишин Олександра Василівна

79000, Львів, вул. Генерала Чупринки, 45

E-mail: Istasyshyn@gmail.com

\section{Information about the author:}

Stasyshyn Oleksandra V. - Doctor of Medical Sciences, Leading researcher of SI «Institute of blood pathology and transfusion medicine of NAMS of Ukraine», Lviv, Ukraine. ORCID ID: orcid.org/0000-0002-8366-5926

Address for correspondence:

Oleksandra Stasyshyn

79000, Lviv, General Chuprynka str., 45

E-mail: Istasyshyn@gmail.com
Надійшла до редакції/Received: 08.01.2021

Прийнято до друку/Accepted: 15.01.2021

ТЕСТОВІ ЗАПИТАННЯ

(один або декілька правильних варіантів відповідей на кожне запитання)

1. Який рівень активності FVIII вважають нормальним?
$\square$ 50-150\%
$\square$ 10-20\%
$\square<10 \%$
$\square<1 \%$

2. Який рівень активності FVIII наявний у пацієнтів із тяжким ступенем гемофілії A?
$\square<1 \%$
$\square 1-5 \%$
$\square 5-50 \%$
$\square$ 50-150\%

3. Коли з'являються перші симптоми захворювання при гемофілії середньотяжкого ступеня?
$\square$ у дошкільному віці
$\square$ у шкільному віці
$\square$ з перших днів життя
$\square$ усі відповіді правильні

4. Золотим стандартом лікування пацієнтів із гемофілією A є:

$\square$ профілактичне лікування концентратами FVIII

$\square$ профілактичне лікування концентратами FVII

$\square$ профілактичне лікування концентратами FV

$\square$ усі відповіді правильні

5. Первинна профілактика полягає у:

$\square$ регулярному введенні концентратів FVIII у дозі 2540 Од./кг $\square$ введенні концентратів FVII щотижня

$\square$ регулярному введенні концентратів FVII у дозі 2540 Од./кг

$\square$ застосуванні аскорбінової кислоти

6. Індивідуалізований підхід до профілактичної терапії базується на:

$\square$ індивідуальному фармакокінетичному профілі, масі тіла, фенотипі кровотечі, рівні фізичної активності, стані суглобів та прихильності пацієнта до лікування

$\square$ масі тіла

$\square$ тяжкості кровотечі

$\square$ усі відповіді правильні

7. Визначте рекомендовану мінімальну концентрацію FVIII для дітей, що ведуть активний спосіб життя (фізичні заняття групи високого ризику):
$\square$ 5-15\%
$\square 3-5 \%$
$\square 1-3 \%$
$\square<1 \%$

8. Вторинну профілактику призначають:

$\square$ пацієнтам із наявними ознаками ураження суглобів, яка спрямована на зниження прогресування гемофілічної артропатії

$\square$ пацієнтам, які не мають ознак артропатій

$\square$ пацієнтам, які не мали відповіді на первинну профілактику

$\square$ пацієнтам, які ведуть активний спосіб життя

\section{Для отримання сертифіката дайте відповідь на тестові запитання в режимі on-line на сайті журналу www.umj.com.ua або надішліть ксерокопію сторінок з відповідями разом з контактною інформацією за адресою: 01001, Київ-1, a/c «В»-82, ТОВ «МОРІOH»}

ПІБ

Поштова адреса: індекс
область
район
місто
вулиця
будинок
квартира
Е-лефон
Е-mail

